\title{
Effects of oral cimetidine on the reproductive system of male rats
}

\author{
XU LIU ${ }^{1}$, YULING JIA ${ }^{2-4}$, LIMING CHONG ${ }^{2-4}$, JUAN JIANG ${ }^{2-4}$, YANG YANG ${ }^{2-4}$, \\ LEI LI ${ }^{2-4}$, AICUI MA ${ }^{2-4}$, ZUYUE SUN ${ }^{2-4}$ and LI ZHOU ${ }^{2-4}$ \\ ${ }^{1}$ Pharmacology and Toxicology Research Laboratory, School of Pharmacy, Fudan University, Shanghai 201203; \\ ${ }^{2}$ Pharmacology and Toxicology Research Laboratory, Shanghai Institute of Planned Parenthood Research, \\ National Evaluation Centre for The Toxicology of Fertility Regulating Drugs; ${ }^{3}$ Key Laboratory of Reproduction \\ Regulation of National Population and Family Planning Commission, Shanghai Institute of Planned Parenthood Research, \\ Reproductive and Developmental Research Institute of Fudan University; ${ }^{4}$ Pharmacology and Toxicology Research \\ Laboratory, Reproductive and Developmental Research Institute of Fudan University, Shanghai 200032, P.R. China
}

Received March 28, 2017; Accepted September 26, 2017

DOI: $10.3892 /$ etm.2018.6065

\begin{abstract}
Cimetidine is widely used for the treatment of digestive tract ulcers, but it induces testis injury. To explore the mechanisms underlying cimetidine-induced toxicity towards the testis, the effects of oral cimetidine on the reproductive system of male rats were assessed. Cimetidine was orally administered to male rats at 20,40 or $120 \mathrm{mg} / \mathrm{kg} /$ day for 9 weeks. The rats were then euthanized, and serum, testis, epididymis, prostate gland, seminal vesicle, preputial gland, levator ani muscle and sphincter ani samples were collected. Sperm parameters were obtained by computer-assisted sperm analysis. Serum hormone levels were measured by ELISA. Protein expression levels were detected by immunohistochemistry. Apoptosis was assessed with the DeadEnd ${ }^{\mathrm{TM}}$ Colorimetric Apoptosis Detection System. The results indicated that the sperm average path velocity, straight line velocity and curvilinear velocity were significantly decreased in the $120 \mathrm{mg} / \mathrm{kg}$ cimetidine group compared with the control group, while luteinizing hormone and testosterone levels were significantly higher compared with the control group. Testicular lesions were observed by histopathology in the $120 \mathrm{mg} / \mathrm{kg}$ cimetidine group. The amounts of cells positive for cyclooxygenase-2 (COX-2) and nuclear factor $\kappa \mathrm{B}(\mathrm{NF}-\kappa \mathrm{B})$ were increased in the $120 \mathrm{mg} / \mathrm{kg}$ cimetidine group compared with the control group. The amounts of cells positive for iNOS were increased in all cimetidine treatment groups. In addition, apoptotic cells were significantly more abundant in
\end{abstract}

Correspondence to: Professor Li Zhou, Pharmacology and Toxicology Research Laboratory, Shanghai Institute of Planned Parenthood Research, National Evaluation Centre for The Toxicology of Fertility Regulating Drugs, 2140 Xietu Road, Shanghai 200032, P.R. China

E-mail: zhoulijss@163.com

Key words: cimetidine, male, oral, reproductive toxicity, cyclooxygenase-2, inducible nitric oxide synthase, nuclear factor- $\kappa \mathrm{B}$ the $120 \mathrm{mg} / \mathrm{kg}$ cimetidine group compared with the control group, as indicated by terminal deoxynucleotidyl transferase deoxyuridine triphosphate nick end labeling. Overall, 9 weeks of oral cimetidine induced pathological changes in the testicles and hormone secretion disorder in rats. COX-2, iNOS and $\mathrm{NF}-\kappa \mathrm{B}$ upregulation and induction of apoptosis may be associated with the reproductive toxicity caused by cimetidine.

\section{Introduction}

Cimetidine is a drug approved by the Food and Drug Administration (USA) for the reduction of gastric acid secretion. It is used to alleviate the symptoms of peptic ulcer, erosive gastroesophageal reflux and hypersecretory conditions, including Zollinger-Ellison syndrome, and multiple endocrine adenomas (1). Cimetidine significantly inhibits the secretion of gastric acid caused by food, histamine, pentagastrin, caffeine and insulin. It is an $\mathrm{H}_{2}$ receptor antagonist and competitively blocks dihydrotestosterone (DHT) receptors in the pituitary gland, hypothalamus and other tissues that require DHT $(2,3)$. DHT is a sterol transformed from testosterone (T), and functions as the so-called real male hormone in accessory glands, including the prostate and seminal vesicle gland. It is referred to as a weak nonsteroidal anti-androgen $(4,5)$. Cimetidine has been demonstrated to have important immunoregulatory and anticancer effects, which further broadened its clinical applications $(6,7)$. Cimetidine is widely distributed in various types of tissue; thus, its pharmacological action is broad. Adverse effects, including loss of libido, impotence and decreased sperm, have been reported by male patients treated with cimetidine (8).

Cimetidine causes a significant reduction of testicular weight, tubular diameter and seminiferous epithelium height (9-12). In addition, irregular tubules exhibiting disorganized epithelium, intraepithelial vacuolization, loss of germ cells by apoptosis and sloughed germ cells filling the tubular lumen have been observed (9-14). França et al (9) identified a significant reduction of peritubular tissue in testis samples from cimetidine-treated rats. In addition, the presence of apoptotic peritubular cells and disordered basal lamina around apparently normal seminiferous tubules 
indicated that peritubular cells are the primary targets of cimetidine (9). Beltrame et al (15) reported that cimetidine causes testicular vascular atrophy by inducing apoptosis in vascular cells. The impairment of the testicular microvasculature by cimetidine may be exerted through a possible antagonist effect of on $\mathrm{H}_{2}$ - and/or androgen receptors in vascular cells (15). Koshimizu et al (16) demonstrated that cimetidine induces significant epithelial damage. It may prevent the translocation of nuclear factor (NF)- $\mathrm{kB}$ to the nucleus and interfere with NF- $\kappa \mathrm{B}$-mediated control of smooth muscle cell apoptosis (16). NF- $\mathrm{kB}$ is important in inflammation, immune responses, tumorigenesis and protection against apoptosis (17-19). It activates the transcription of numerous genes, several of which directly block the activation of caspases involved in apoptosis (20); these genes include cyclooxygenase (COX)-2 and inducible nitric oxide (NO) synthase (iNOS) (21). COX-2 is an inducible form of $\mathrm{COX}$ and has an important role in inflammation and tumor proliferation (22). iNOS induces NO formation, leading to cytotoxicity (23). During infection, NO is detected at high levels in the immune system and has host-protective effects (24). It may be an important mediator of acute and chronic inflammatory signals in different forms of inflammation in humans and animals (25). Studies have demonstrated that $\mathrm{NO}$ and reactive oxygen species trigger cell death. The oxidation products of NO cause lipid peroxidation (26-28). Furthermore, iNOS binds specifically to COX-2 and enhances its catalytic activity (29).

To further understand the mechanisms of reproductive toxicity induced by cimetidine, the present study evaluated the effects of a 9-week oral cimetidine treatment on the reproductive system of male Sprague Dawley (SD) rats, assessing serum levels of reproductive hormones, the sperm count and histopathologic features of the testis. In addition, COX-2, iNOS, and NF- $\mathrm{kB}$ expression levels, and apoptosis in testis samples were detected.

\section{Materials and methods}

Animals and treatment. A total of 32 male SD rats (weight, 430-530 g; age, 16-weeks) were purchased from SIPPR-B\&K Laboratory Animal Corp. (Shanghai, China; license no. SCXK; 2008-0016). They were housed at two animals per cage in an animal room kept at $20-26^{\circ} \mathrm{C}$ with $40-70 \%$ relative humidity, under a 12-h light/dark cycle. The animals had free access to tap water and food. This study was approved by the Ethics Committee Shanghai Institute of Planned Parenthood Research Animal Care (Shanghai, China). Discomfort, distress and pain to the animals were strictly minimized.

The animals were randomly assigned into 4 groups of 8 . Group I served as a control group and was administered $0.5 \%$ sodium carboxymethyl cellulose. Groups II, III and IV received 20,40 and $120 \mathrm{mg} / \mathrm{kg}$ body weight of cimetidine, respectively, by gavage for 63 consecutive days; $40 \mathrm{mg} / \mathrm{kg}$ represents the therapeutic dose used in humans. The rats were sacrificed on the 64th day ( $24 \mathrm{~h}$ after the final treatment) under anesthesia with $3 \%$ pentobarbital sodium $(35 \mathrm{mg} / \mathrm{kg})$. Cimetidine was supplied by Wuhan Shengtianyu Biological Technology Co., Ltd (Wuhan, China) and mixed with $0.5 \%$ sodium carboxymethyl cellulose prior to use.

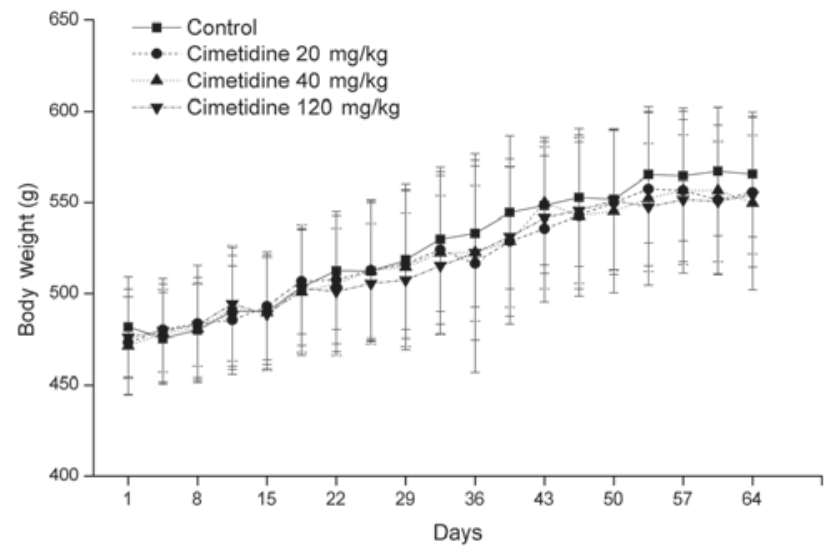

Figure 1. Effects of cimetidine on body weight of male rats. Values are expressed as the mean \pm standard deviation $(n=8)$.

Body and organ weight measurements, and histopathology. Rats were weighed twice a week and sacrificed on the 64th day as described above. The testis, epididymis, prostate gland, seminal vesicle, preputial gland, levator ani muscle and sphincter ani were collected and weighed. Organ weights were recorded in $\mathrm{g}$ and expressed as $\mathrm{g} / 100 \mathrm{~g}$ body weight. The testis samples were then fixed in neutral $10 \%$ formalin for $24 \mathrm{~h}$ at room temperature, dehydrated in ethanol, cleared in xylene and embedded in paraffin. Slices of 4-6 $\mu \mathrm{m}$ thickness were prepared and stained with hematoxylin $(5 \mathrm{~min}$ at room temperature) and eosin ( $2 \mathrm{~min}$ at room temperature). The sections were then examined under a light microscope.

Sperm parameters. The epididymis was isolated and cleared of adhering tissues. The cauda epididymis was extracted, minced and incubated in $4 \mathrm{ml} \mathrm{M} 199$ at $37^{\circ} \mathrm{C}$ for $5 \mathrm{~min}$, to allow sperm cells to leave the epididymal tubules. A total of $10 \mu 1$ sperm suspension was then added to the sperm counting plate. Sperm parameters were collected by computer-assisted sperm analysis with the HTM-IVOS (Hamilton Thorne, Beverly, Ma, USA) and evaluated using the HTM-TOXIVOS Toxicology software program (Rat Head Toxicology, Hamilton-Thorne Research, Beverly, MA, USA) version 12.

Serum hormone levels. At the end of the experimental period, rats were anesthetized with $3 \%$ pentobarbital sodium. Blood samples were collected via the abdominal aorta and centrifuged for $15 \mathrm{~min}\left(2,095 \mathrm{x} \mathrm{g}, 4^{\circ} \mathrm{C}\right)$. The resulting supernatants were immediately stored at $-80^{\circ} \mathrm{C}$ until use for hormone level measurements. Follicle-stimulating hormone (FSH), luteinizing hormone (LH) and testosterone (T) concentrations were measured by FSH, LH and T ELISA kits (Hufeng Chemical Co., Ltd, Nantong, China; cat. nos. F14574-A, F14573-A and F4421-A, respectively) according to the manufacturer's instructions.

Immunohistochemistry. Paraffin sections of testis samples were deparaffinized and rehydrated. Antigens were retrieved by incubating the sections in a microwave oven in sodium citrate buffer $(10 \mathrm{mM}$; pH 6.0) for $15 \mathrm{~min}$. Sections were brought to room temperature and rinsed with PBS. Then the sections were blocked using $5 \%$ bovine serum albumin (Boster 
Table I. Effects of cimetidine on weight of organs of male rats associated with the reproductive system.

\begin{tabular}{|c|c|c|c|c|}
\hline \multirow[b]{2}{*}{ Organ } & \multirow[b]{2}{*}{ Control } & \multicolumn{3}{|c|}{ Cimetidine (mg/kg) } \\
\hline & & 20 & 40 & 120 \\
\hline \multicolumn{5}{|l|}{ Testis } \\
\hline (g) & $3.384 \pm 0.173$ & $3.516 \pm 0.337$ & $3.445 \pm 0.269$ & $3.466 \pm 0.231$ \\
\hline (g/100 g b.w.) & $0.601 \pm 0.067$ & $0.633 \pm 0.049$ & $0.630 \pm 0.074$ & $0.628 \pm 0.022$ \\
\hline \multicolumn{5}{|l|}{ Epididymis } \\
\hline (g) & $1.298 \pm 0.080$ & $1.264 \pm 0.105$ & $1.281 \pm 0.100$ & $1.274 \pm 0.119$ \\
\hline (g/100 g b.w.) & $0.231 \pm 0.024$ & $0.229 \pm 0.025$ & $0.234 \pm 0.027$ & $0.230 \pm 0.011$ \\
\hline \multicolumn{5}{|l|}{ Preputial gland } \\
\hline$(\mathrm{g})$ & $0.091 \pm 0.015$ & $0.092 \pm 0.024$ & $0.108 \pm 0.028$ & $0.099 \pm 0.018$ \\
\hline (g/100 g b.w.) & $0.016 \pm 0.003$ & $0.017 \pm 0.005$ & $0.020 \pm 0.005$ & $0.018 \pm 0.003$ \\
\hline \multicolumn{5}{|l|}{ Prostate gland } \\
\hline (g) & $1.495 \pm 0.161$ & $1.582 \pm 0.197$ & $1.579 \pm 0.178$ & $1.542 \pm 0.275$ \\
\hline (g/100 g b.w.) & $0.266 \pm 0.043$ & $0.285 \pm 0.030$ & $0.287 \pm 0.024$ & $0.278 \pm 0.040$ \\
\hline \multicolumn{5}{|l|}{ Seminal vesicle } \\
\hline (g) & $1.724 \pm 0.135$ & $1.729 \pm 0.296$ & $1.856 \pm 0.209$ & $2.020 \pm 0.273^{\mathrm{a}}$ \\
\hline (g/100 g b.w.) & $0.307 \pm 0.038$ & $0.315 \pm 0.072$ & $0.338 \pm 0.033$ & $0.368 \pm 0.061$ \\
\hline \multicolumn{5}{|c|}{ Levator ani muscle } \\
\hline (g) & $0.317 \pm 0.048$ & $0.310 \pm 0.033$ & $0.292 \pm 0.038$ & $0.310 \pm 0.036$ \\
\hline (g/100 g b.w.) & $0.056 \pm 0.008$ & $0.056 \pm 0.006$ & $0.053 \pm 0.008$ & $0.056 \pm 0.006$ \\
\hline \multicolumn{5}{|l|}{ Sphincter ani } \\
\hline (g) & $1.167 \pm 0.084$ & $1.169 \pm 0.134$ & $1.171 \pm 0.107$ & $1.141 \pm 0.113$ \\
\hline (g/100 g b.w.) & $0.207 \pm 0.018$ & $0.212 \pm 0.034$ & $0.214 \pm 0.021$ & $0.207 \pm 0.015$ \\
\hline
\end{tabular}

${ }^{\mathrm{a}} \mathrm{P}<0.05$ vs. control group. Values are expressed as the mean \pm standard deviation $(\mathrm{n}=8)$. b.w., body weight.

Table II. Effects of cimetidine on sperm parameters of male rats.

\begin{tabular}{|c|c|c|c|c|}
\hline \multirow[b]{2}{*}{ Parameter } & \multirow[b]{2}{*}{ Control } & \multicolumn{3}{|c|}{ Cimetidine (mg/kg) } \\
\hline & & 20 & 40 & 120 \\
\hline Sperm count $\left(10^{6} / \mathrm{ml}\right)$ & $9.1 \pm 4.5$ & $6.9 \pm 2.8$ & $5.8 \pm 3.1$ & $6.0 \pm 1.8$ \\
\hline Sperm motility (\%) & $51.5 \pm 20.3$ & $60.2 \pm 14.5$ & $65.3 \pm 13.3$ & $49.5 \pm 11.2$ \\
\hline Progressive sperm count $\left(10^{6} / \mathrm{ml}\right)$ & $1.7 \pm 1.1$ & $1.4 \pm 0.8$ & $1.3 \pm 0.5$ & $0.9 \pm 0.6$ \\
\hline $\operatorname{VAP}(\mu \mathrm{m} / \mathrm{sec})$ & $243.2 \pm 40.5$ & $240.6 \pm 24.5$ & $249.5 \pm 11.6$ & $205.5 \pm 15.6^{\mathrm{a}}$ \\
\hline $\mathrm{VSL}(\mu \mathrm{m} / \mathrm{sec})$ & $167.1 \pm 30.7$ & $165.9 \pm 18.6$ & $161.2 \pm 9.8$ & $139.6 \pm 10.6^{\mathrm{a}}$ \\
\hline $\operatorname{VCL}(\mu \mathrm{m} / \mathrm{sec})$ & $417.7 \pm 80.5$ & $412.0 \pm 41.6$ & $427.1 \pm 25.9$ & $348.9 \pm 31.8^{\mathrm{a}}$ \\
\hline
\end{tabular}

${ }^{\text {ap }}<0.05$ vs. control group. Values are expressed as the mean \pm standard deviation $(n=8)$. VAP, average path velocity of sperm; VSL, straight line velocity of sperm; VCL, curvilinear velocity of sperm.

Biological Technology Co., Ltd., Pleasanton, CA, USA) at room temperature for $20 \mathrm{~min}$. Subsequently, the tissues were incubated with primary antibodies overnight at $4^{\circ} \mathrm{C}$. Antibodies against COX-2 (cat. no. BA0738, Boster Biological Technology Co., Ltd., China) and NF-кB (p52) (cat. no. BA1873, Boster Biological Technology Co., Ltd.) were diluted at 1:200, 1:200 and 1:100 in PBS, respectively. After $12 \mathrm{~h}$, the sections were washed with PBS and incubated for $30 \mathrm{~min}$ with biotin labeled goat anti rabbit IgG secondary antibodies (cat. no. SA1022; included in a kit SABC-POD (rabbit IgG) kit for immediate use provided by Boster Biological Technology Co., Ltd.) at room temperature. Bands were visualized using diaminobenzidine (DAB) chromogenic agent (Boster Biological Technology Co., Ltd.) at room temperature for 5-10 $\mathrm{min}$. Sections were counterstained with Mayer's hematoxylin at room temperature for $5 \mathrm{~min}$. Finally, the mean optical density values were analyzed 
with ImageJ software v. 1.47 (National Institutes of Health, Bethesda, MD, USA).

Terminal deoxynucleotidyl transferase (TdT) deoxyuridine triphosphate nick end labeling (TUNEL) assay. TUNEL staining was performed using the DeadEnd ${ }^{\mathrm{TM}}$ Colorimetric Apoptosis Detection System (cat. no. G3250; Promega Corp., Madison, WI, USA). Testicular sections were deparaffinized, hydrated and incubated with $20 \mu \mathrm{g} / \mathrm{ml}$ proteinase K (Promega Corp.) for $10 \mathrm{~min}$ at room temperature. The sections were then equilibrated with equilibration buffer at room temperature for $10 \mathrm{~min}$. Subsequently, the TdT reaction mix was added to the tissue sections on an area no larger than $5 \mathrm{~cm}^{2}$. The slides were incubated for $60 \mathrm{~min}$ at $37^{\circ} \mathrm{C}$ in a humidified chamber. The reaction was stopped by transferring the slides to $2 \mathrm{X}$ saline-sodium citrate for $15 \mathrm{~min}$. Endogenous peroxidase was inactivated by incubation with $0.3 \%$ hydrogen peroxide for $5 \mathrm{~min}$ at room temperature. The sections were incubated with streptavidin horseradish peroxidase (diluted at 1:500 in PBS) for $30 \mathrm{~min}$ at room temperature and developed with $\mathrm{DAB}$ at room temperature for 5 min until a brown background appeared. Finally, the samples were counterstained with Mayer's hematoxylin. The mean optical density values were analyzed with ImageJ software v. 1.47.

Statistical analysis. Values are expressed as the mean \pm standard deviation. Statistical analyses were performed using SPSS version 11.5 (SPSS, Inc., Chicago, IL, USA). One-way analysis of variance followed by Dunnett's test was used to assess statistical differences between the control and treatment groups. $\mathrm{P}<0.05$ was considered to indicate a statistically significant difference.

\section{Results}

Body and organ weight. The body weight of treated rats was not significantly different from that in the control group throughout the treatment period (Fig. 1). In addition, testis, epididymis, prostate gland, preputial gland, levator ani muscle and sphincter ani weights were similar in the control and treatment groups. Administration of $120 \mathrm{mg} / \mathrm{kg}$ cimetidine significantly increased the seminal vesicle weight compared with control group. However, no significant difference in relative seminal vesicle weight $(\mathrm{g} / 100 \mathrm{~g}$ body weight) was observed between the $120 \mathrm{mg} / \mathrm{kg}$ cimetidine group and control group (Table I).

High-dose cimetidine causes decreased sperm average path velocity (VAP), straight line velocity (VSL) and curvilinear velocity $(V C L)$. Sperm count, sperm motility, progressive sperm count, VAP, VSL and VCL are presented in Table II. Administration of $120 \mathrm{mg} / \mathrm{kg}$ cimetidine for 9 weeks significantly decreased sperm VAP, VSL and VCL compared with the control group $(\mathrm{P}<0.05)$. Sperm motilities were not significantly different between the control and cimetidine treatment groups.

High-dose cimetidine increases LH and T levels. Total serum concentrations of unconjugated $\mathrm{FSH}, \mathrm{LH}$ and $\mathrm{T}$ are presented in Fig. 2A, B and C, respectively. LH and T levels
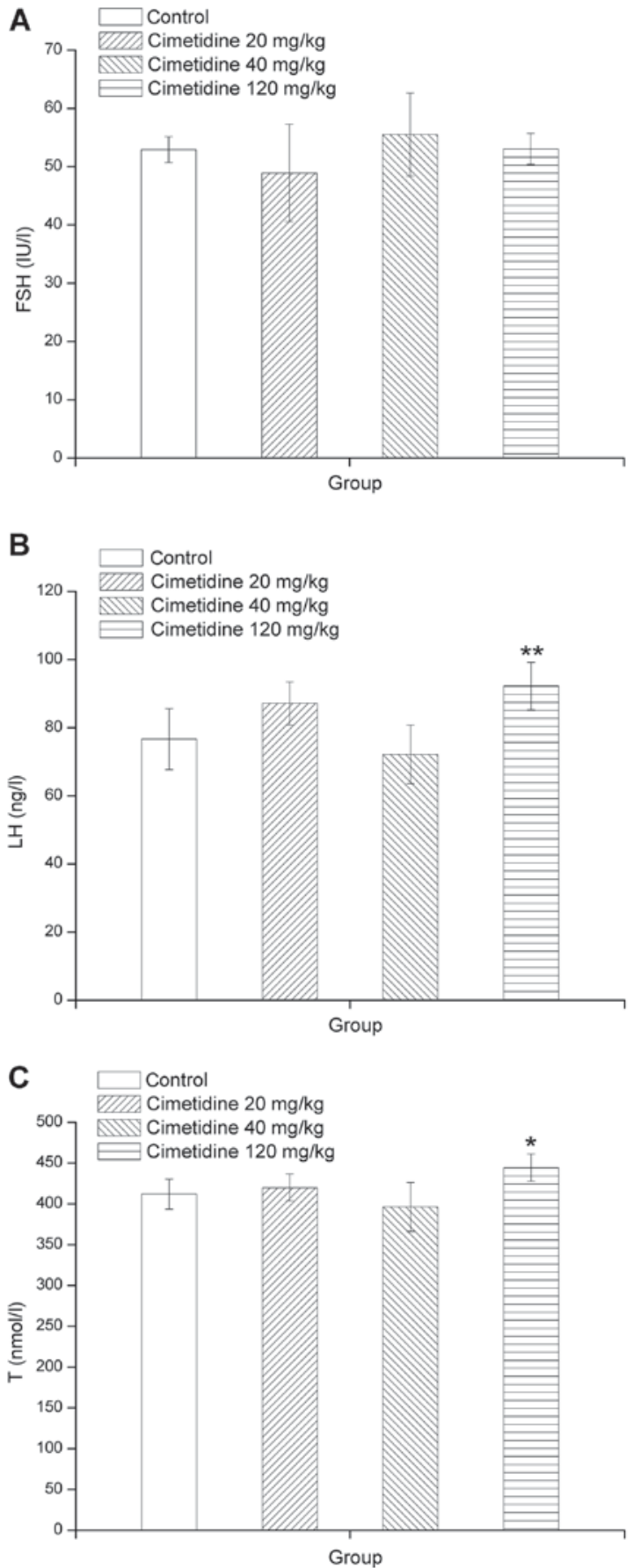

Figure 2. Effects of cimetidine on serum (A) FSH, (B) LH and (C) T levels in male rats. Values are expressed as the mean \pm standard deviation $(n=8)$. ${ }^{*} \mathrm{P}<0.05 ;{ }^{* *} \mathrm{P}<0.01$ vs. control. FSH, follicle stimulating hormone; $\mathrm{LH}$, luteinizing hormone; $\mathrm{T}$, testosterone.

were significantly higher in the $120 \mathrm{mg} / \mathrm{kg}$ cimetidine group compared with those in the control group $(\mathrm{P}<0.05$ or $\mathrm{P}<0.01)$. However, serum FSH levels exhibited no significant differences from those in the control group.

High-dose cimetidine causes testicular lesions. The photomicrographs in Fig. 3 illustrate the different histopathologic changes observed in testis samples from rats treated with cimetidine. The control, $20 \mathrm{mg} / \mathrm{kg}$ cimetidine and $40 \mathrm{mg} / \mathrm{kg}$ cimetidine groups exhibited a compact and regular arrangement of cells in the seminiferous tubules 
A

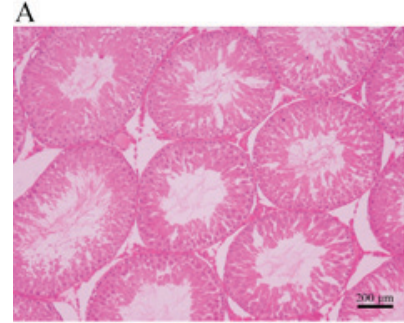

$\mathrm{C}$

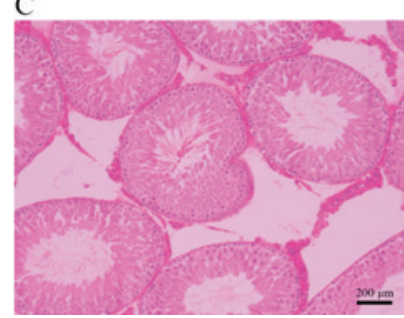

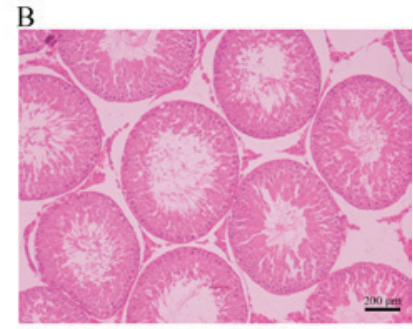

D

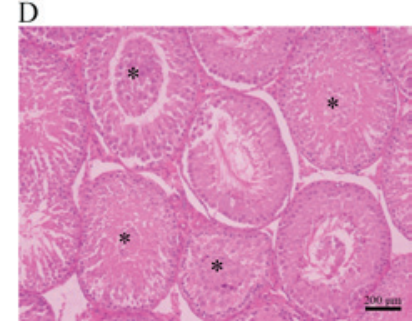

Figure 3. Histopathological photomicrographs of cross-sections of testis samples from the (A) control, (B) $20 \mathrm{mg} / \mathrm{kg}$ cimetidine, (C) $40 \mathrm{mg} / \mathrm{kg}$ cimetidine and (D) $120 \mathrm{mg} / \mathrm{kg}$ cimetidine groups (hematoxylin and eosin staining; magnification, x100; scale bar, $200 \mu \mathrm{m}$ ). The control, $20 \mathrm{mg} / \mathrm{kg}$ cimetidine and $40 \mathrm{mg} / \mathrm{kg}$ cimetidine groups displayed a compact and regular arrangement of cells in the seminiferous tubules. The $120 \mathrm{mg} / \mathrm{kg}$ group exhibited cell material shedding in the lumen of seminiferous tubules (asterisks).

A

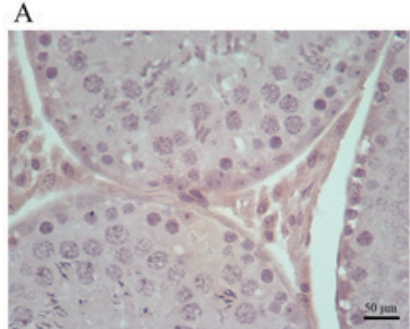

C

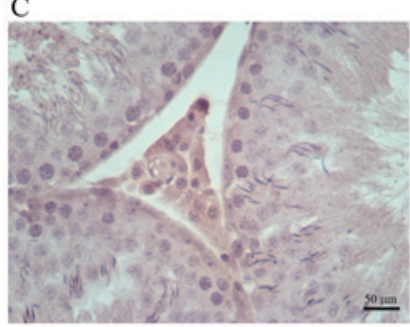

B

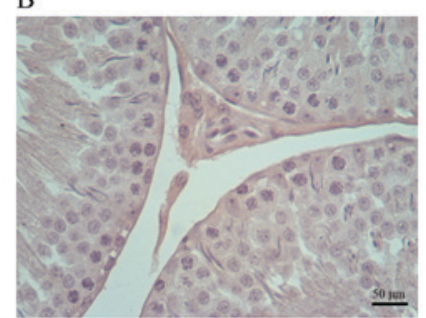

$\mathrm{D}$

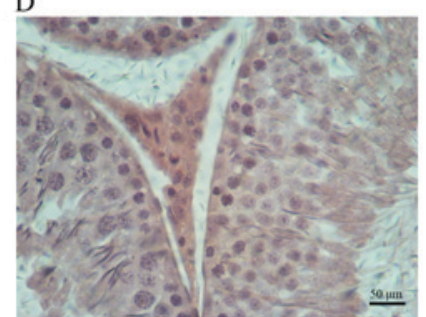

Figure 4. Immunohistochemical staining for COX-2 in testis samples. COX-2 expression in the (A) control, (B) $20 \mathrm{mg} / \mathrm{kg}$ cimetidine, (C) $40 \mathrm{mg} / \mathrm{kg}$ cimetidine and (D) $120 \mathrm{mg} / \mathrm{kg}$ cimetidine groups (counterstain with Mayer's hematoxylin; magnification, x400; scale bar, $50 \mu \mathrm{m}$ ). The amount of Leydig cells with staining for COX-2 was increased in the $120 \mathrm{mg} / \mathrm{kg}$ cimetidine group compared with that in the control group. COX-2, cyclooxygenase 2 .

(Fig. 3A, B and C, respectively). Treatment with cimetidine at $120 \mathrm{mg} / \mathrm{kg}$ caused testicular lesions on histopathological examination. The $120 \mathrm{mg} / \mathrm{kg}$ group displayed cell material shedding in the lumen of seminiferous tubules (Fig. 3D).

High-dose cimetidine causes increased expression of $\mathrm{COX}-2$ and $N F-\kappa B$. Immunohistochemical analysis indicated increased amounts of cells positive for COX-2, iNOS and NF- $\kappa$ B in testis samples from cimetidine-treated rats (Figs. 4-6). The amount of cells positive for COX-2 and $\mathrm{NF}-\kappa \mathrm{B}$ was increased in the $120 \mathrm{mg} / \mathrm{kg}$ cimetidine group (Figs. 4D and 6D; Table III) compared with the control group; furthermore, the amount

A

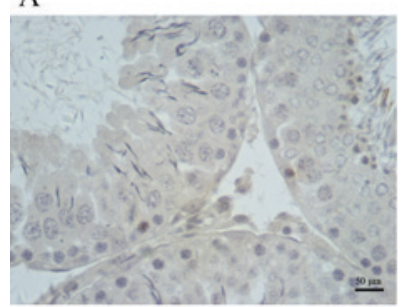

C

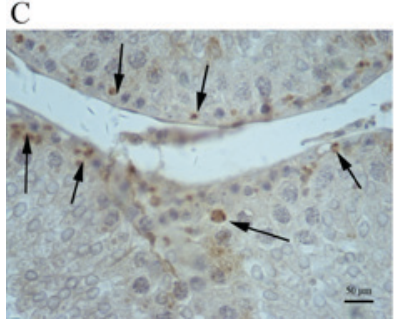

B

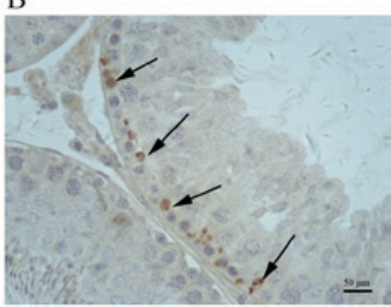

$\mathrm{D}$

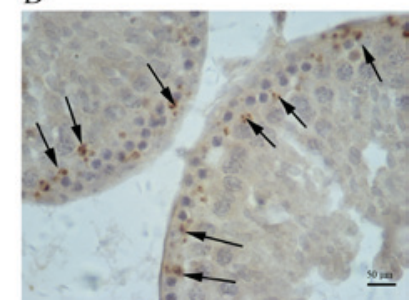

Figure 5. Immunohistochemical staining for iNOS in testis samples. iNOS expression in the (A) control, (B) $20 \mathrm{mg} / \mathrm{kg}$ cimetidine, (C) $40 \mathrm{mg} / \mathrm{kg}$ cimetidine and (D) $120 \mathrm{mg} / \mathrm{kg}$ cimetidine groups (counterstain with Mayer's hematoxylin; magnification, $\mathrm{x} 400$; scale bar, $50 \mu \mathrm{m}$ ). Compared with that in the control group (no expression), the amount of cells expressing iNOS was increased in all cimetidine treatment groups, including the 20, 40 and $120 \mathrm{mg} / \mathrm{kg}$ groups (arrows). iNOS, inducible nitric oxide synthase.

A

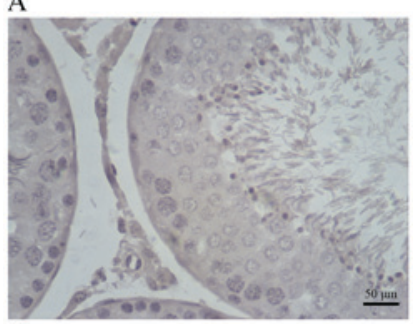

C

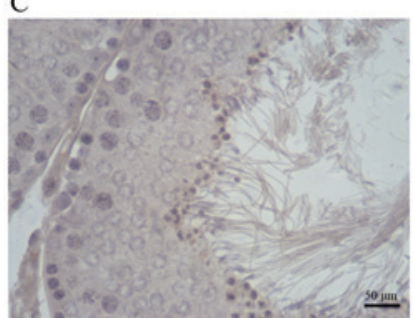

B

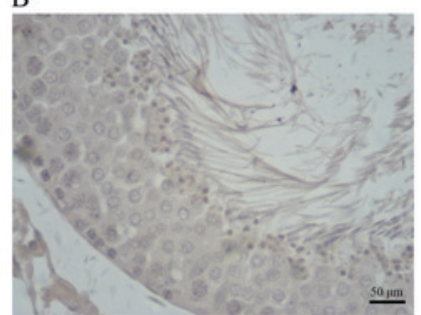

D

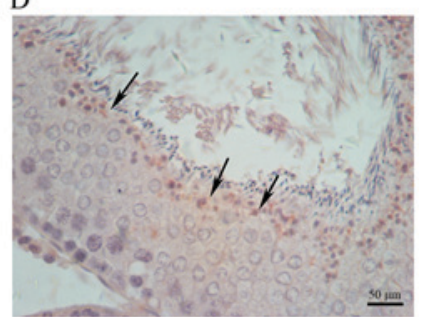

Figure 6. Immunohistochemical staining for NF- $\kappa B$ in testis samples. NF- $\mathrm{kB}$ expression in the (A) control, (B) $20 \mathrm{mg} / \mathrm{kg}$ cimetidine, (C) $40 \mathrm{mg} / \mathrm{kg}$ cimetidine and (D) $120 \mathrm{mg} / \mathrm{kg}$ cimetidine groups (counterstain with Mayer's hematoxylin; magnification, $x 400$; scale bar, $50 \mu \mathrm{m}$ ). The amount of cells expressing NF- $\mathrm{kB}$ was increased in the $120 \mathrm{mg} / \mathrm{kg}$ cimetidine group compared with that in the control group (arrows). NF, nuclear factor.

of cells positive for iNOS was increased in all cimetidine treatment groups, including the 20,40 and $120 \mathrm{mg} / \mathrm{kg}$ groups (Fig. 5B, C and D; Table III). Notably, the cells expressing iNOS were the Sertoli cells, but further research is required to validate this result. There was no change in the type of cells with iNOS, COX-2 and NF- $\mathrm{B}$ expression upon treatment.

High-dose cimetidine causes apoptosis in testicles. In testicular sections from the control, $20 \mathrm{mg} / \mathrm{kg}$ cimetidine and $40 \mathrm{mg} / \mathrm{kg}$ cimetidine groups, the seminiferous tubules rarely displayed any TUNEL-stained cells, while obvious TUNEL-positive cells were idenfied in seminiferous tubules 
Table III. Expression of COX-2, iNOS and NF-кB, and apoptosis in testis of male rats.

Cimetidine $(\mathrm{mg} / \mathrm{kg})$

\begin{tabular}{lcccc}
\cline { 3 - 4 } Protein/item & Control & 20 & 40 & 60 \\
\hline COX-2 & $0.167 \pm 0.011$ & $0.169 \pm 0.013$ & $0.172 \pm 0.006$ & $0.192 \pm 0.009^{\mathrm{a}}$ \\
iNOS & $0.312 \pm 0.020$ & $0.341 \pm 0.009^{\mathrm{a}}$ & $0.334 \pm 0.005^{\mathrm{a}}$ & $0.358 \pm 0.011^{\mathrm{b}}$ \\
NF-kB & $0.333 \pm 0.010$ & $0.330 \pm 0.011$ & $0.338 \pm 0.021$ & $0.355 \pm 0.008^{\mathrm{a}}$ \\
Apoptosis & $0.327 \pm 0.016$ & $0.319 \pm 0.022$ & $0.331 \pm 0.019$ & $0.363 \pm 0.013^{\mathrm{b}}$
\end{tabular}

${ }^{\mathrm{a}} \mathrm{P}<0.05$; ${ }^{\mathrm{b}} \mathrm{P}<0.01$ vs. control group. Values are expressed as the mean \pm standard deviation $(\mathrm{n}=8)$. iNOS, inducible nitric oxide synthase; NF, nuclear factor; $\mathrm{COX}$, cyclooxygenase.

from the $120 \mathrm{mg} / \mathrm{kg}$ cimetidine group (Fig. 7) compared with control group. The results of the semi-quantitative analysis of the images are displayed in Table III.

\section{Discussion}

Cimetidine, a weak nonsteroidal anti-androgenic drug, induces testis abnormalities in male rats after intraperitoneal injection $(13,16)$. In previous studies, it was demonstrated that cimetidine causes significant structural alterations in the seminiferous tubules, including intraepithelial vacuolization, loss of germ cells by apoptosis, decrease in epithelial parameters and the area of the smooth muscle layer of the vas deferens, and vascular cell apoptosis $(10,13,16)$. However, the underlying mechanisms have remained elusive.

In the present study, cimetidine had no adverse influence on the body and relative weight of reproductive organs after 9 weeks of treatment by gavage; in another study (9), significant decreases in epididymal, ventral prostate and combined seminal vesicle, as well as coagulating gland weights were identified after a 59-day treatment with a high dose $(250 \mathrm{mg} / \mathrm{kg})$ administered by intraperitoneal injection. The discrepancy may be caused by the differences in dosage and administration route. The dose of $250 \mathrm{mg} / \mathrm{kg}$ is much higher than the highest dose $(120 \mathrm{mg} / \mathrm{kg})$ used in the present study. In addition, intraperitoneal injection results in higher bioavailability compared with oral administration used in the present study.

The sperm count and progressive sperm count had a decreasing trend with the increasing dosage of the drug, although no statistical significance was reached. A possible explanation is that cimetidine has an adverse effect on spermatogenic cells to a certain degree. VAP, VSL and VCL are valuable parameters reflecting sperm motility. In the present study, VAP, VSL and VCL were significantly decreased in the $120 \mathrm{mg} / \mathrm{kg}$ cimetidine group compared with those in the control group. Thus, it was deduced that cimetidine may have adverse effects on the activation of spermatozoon motility. The underlying mechanisms require further exploration.

For hormone signaling, serum T, LH and FSH levels were assessed after a nine-week treatment. $\mathrm{LH}$ and $\mathrm{T}$ levels were significantly increased in the $120 \mathrm{mg} / \mathrm{kg}$ cimetidine group compared with those in the control group. In another study (30), elevated T levels were also detected, but LH levels
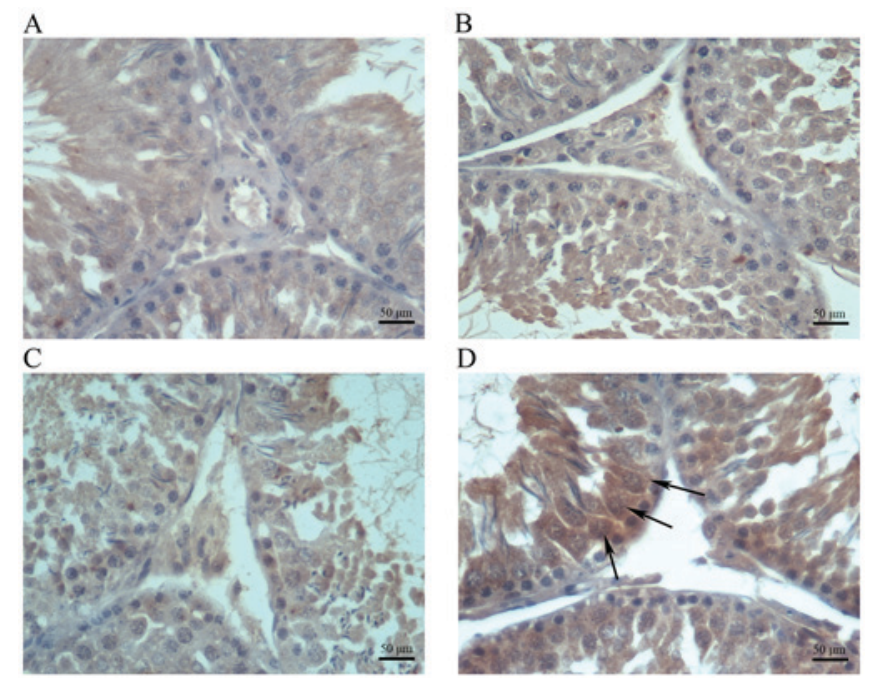

Figure 7. TUNEL staining in the (A) control, (B) $20 \mathrm{mg} / \mathrm{kg}$ cimetidine, (C) $40 \mathrm{mg} / \mathrm{kg}$ cimetidine and (D) $120 \mathrm{mg} / \mathrm{kg}$ cimetidine groups (counterstain with Mayer's hematoxylin; magnification, $\mathrm{x} 400$; scale bar, $50 \mu \mathrm{m}$ ). Brown staining indicates TUNEL-positive cells. Obvious TUNEL-positive cells were observed in seminiferous tubules of the $120 \mathrm{mg} / \mathrm{kg}$ cimetidine group (arrows). TUNEL, terminal deoxynucleotidyl transferase deoxyuridine triphosphate nick end labeling.

remained unchanged. In two other studies on male patients, increased LH and T levels were also reported $(4,5)$. Cimetidine competitively blocks DHT receptors and is referred to as a weak nonsteroidal anti-androgen (2-5). It increases LH levels, presumably by antagonizing the feedback control of gonadotrophin secretion by androgens. An alternative explanation is that cimetidine desensitizes androgen receptors and inhibits the negative feedback for gonadotrophin secretion. Subsequent to increased LH levels, an elevation in T levels occurs. However, in the present study, FSH levels were not changed by cimetidine. Generally speaking, FSH and LH are synthesized and secreted by gonadotropic cells in the anterior pituitary gland. Serum levels of FSH and LH are adjusted by negative feedback. In the present study, only elevated serum LH levels were detected, while serum FSH was unchanged after 9 weeks of cimetidine treatment. From this, it was deduced that FSH is less sensitive to the effects of cimetidine than LH.

As revealed by histopathology, cimetidine caused significant structural alterations in seminiferous tubules, 
including blocked tubular lumen by deciduous germ cells Immunohistochemistry revealed increased amounts of cells positive for COX-2, iNOS and $\mathrm{NF}-\kappa \mathrm{B}$ after cimetidine treatment. In a previous study (16), enhanced $N F-\kappa B$ expression was detected in the cytoplasm of smooth muscle cells of the vas deferens. In the present study, Enhanced NF- $\kappa \mathrm{B}$ expression was detected in spermatogenic cells in the $120 \mathrm{mg} / \mathrm{kg}$ cimetidine group.

Oxidative stress and subsequent activation of signaling kinases may stimulate $\mathrm{NF}-\kappa \mathrm{B}(31,32)$. NF- $\kappa \mathrm{B}$ is a transcription factor with an important role in inducing genes involved in physiological processes, and is also activated in response to injury, infection and inflammation $(33,34)$. It has a crucial role in regulating cell death by inducing apoptosis (35). In general, $\mathrm{NF}-\kappa \mathrm{B}$ is bound to the NF- $\kappa \mathrm{B}$ inhibitor $(\mathrm{I} \kappa \mathrm{B} \alpha)$ protein and activated after stimulation by certain effectors (36). I $\mathrm{B} \alpha$ is phosphorylated by the I $\kappa \mathrm{B}$ kinase complex and degraded by proteasomes. Subsequently, $\mathrm{NF}-\kappa \mathrm{B}$ translocates to the nucleus and activates the target genes leading to cell death (37). In the present study, cell death was detected in the $120 \mathrm{mg} / \mathrm{kg}$ cimetidine group.

COX-2 is induced by inflammatory stimuli (38). In the present study, increased amounts of cells positive for COX-2 were detected in Leydig cells of the $120 \mathrm{mg} / \mathrm{kg}$ cimetidine group. However, the levels of T, which is secreted by Leydig cells, were elevated in the $120 \mathrm{mg} / \mathrm{kg}$ cimetidine group. Elevated serum levels of $\mathrm{T}$ resulted from the combination of two effects: i) An inductive effect caused by LH and ii) an adverse effect to Leydig cells associated with COX-2 expression. Thus, it was deduced that the inductive effect of LH is stronger than the adverse effect caused by COX-2 to yield elevated serum levels of $\mathrm{T}$.

iNOS is modulated by NF- $\kappa$ B. Excessive NO production due to elevated iNOS causes cytotoxicity and induces germ cell apoptosis $(39,40)$. Furthermore, NO is a signaling molecule that has an important role in the pathogenesis of inflammation (41). In all cimetidine treatment groups, iNOS expression was detected. In addition, the cells with iNOS expression were Sertoli cells. These results suggested that Sertoli cells are also affected by cimetidine. Furthermore, 9 weeks of treatment with an excessive dose of cimetidine led to inflammation in the testis and germ cell apoptosis, as demonstrated in the TUNEL assay.

In conclusion, the results of the present study indicated that 9 weeks of oral treatment with cimetidine adversely affects the reproductive system of male rats by disturbing hormone secretion and inducing germ cell apoptosis. A possible mechanism is that toxicity to the testes caused by cimetidine may be associated with NF- $\mathrm{NB}$, iNOS and COX-2 expression, which requires further research for confirmation.

\section{References}

1. Scheinfeld N: Cimetidine: A review of the recent developments and reports in cutaneous medicine. Dermatol Online J 9: 4, 2003.

2. Knigge U, Dejgaard A, Wollesen F, Ingerslev O, Bennett P and Christiansen PM: The acute and long term effect of the $\mathrm{H}$ 2-receptor antagonists cimetidine and ranitidine on the pituitary-gonadal axis in men. Clin Endocrinol (Oxf) 18: 307-313, 1983.

3. Winters SJ, banks JL and Loriaux DL: Cimetidine is an antiandrogen in the rat. Gastroenterology 76: 504-508, 1979.
4. Peden NR, Boyd EJ, Browning MC, Saunders JH and Wormsley KG: Effects of two histamine H2-receptor blocking drugs on basal levels of gonadotrophins, prolactin, testosterone and oestradiol-17ßduring treatment of duodenal ulcer in male patients. Acta Endocrinol (Copenh) 96: 564-568, 1981.

5. Wang C, Lai CL, Lam KC and Yeung KK: Effect of cimetidine on gonadal function in man. Br J Clin Pharmacol 13: 791-794, 1982.

6. Kokhaei P, Barough MS and Hassan ZM: Cimetidine effects on the immunosuppression induced by burn injury. Int Immunopharmacol 22: 273-276, 2014.

7. Kubecova M, Kolostova K, Pinterova D, Kacprzak G and Bobek V: Cimetidine: An anticancer drug? Eur J Pharm Sci 42: 439-444, 2011

8. Peden NR, Cargill JM, Browning MC, Saunders JH and Wormsley KG: Male sexual dysfunction during treatment with cimetidine. Br Med J 1: 659, 1979.

9. França LR, Leal MC, Sasso-Cerri E, Vasconcelos A, Debeljuk L and Russell LD: Cimetidine (Tagamet) is a reproductive toxicant in male rats affecting peritubular cells. Biol Reprod 63: 1403-1412, 2000.

10. Gill M, Sareen ML and Sanyal SN: Effect of H2-receptor antagonists, cimetidine and ranitidine on reproductive functions in male mice. Indian J Exp Biol 29: 900-906, 1991.

11. Pereira OC: Some effects of cimetidine on the reproductive organs of rats. Gen Pharmacol 18: 197-199, 1987.

12. Sasso-Cerri E, Giovanoni M, Hayashi H and Miraglia SM: Morphological alterations and intratubular lipid inclusions as indicative of spermatogenic damage in cimetidine treated rats. Arch Androl 46: 5-13, 2001.

13. Sasso-Cerri E and Miraglia SM: In situ demonstration of both TUNEL-labeled germ cell and Sertoli cell in the cimetidine-treated rats. Histol Histopathol 17: 411-417, 2002.

14. Sasso-Cerri E and Cerri PS: Morphological evidences indicate that the interference of cimetidine on the peritubular components is responsible for detachment and apoptosis of Sertoli cells. Reprod Biol Endocrinol 6: 18, 2008.

15. Beltrame FL, Yamauti CT, Caneguim BH, Cerri PS, Miraglia SM and Sasso-Cerri E: Cimetidine-induced vascular cell apoptosis impairs testicular microvasculaature in adult rats. Histol Histopathol 27: 1343-1351, 2012.

16. Koshimizu JY, Beltrame FL, de Pizzol JP Jr, Cerri PS, Caneguim BH and Sasso-Cerri E: NF- $\kappa$ B overexpression and decreased immunoexpression of $\mathrm{AR}$ in the muscular layer is related to structural damages and apoptosis in cimetidine-treated rat vas deferens. Reprod Biol Endocrinol 11: 29, 2013.

17. Karin M, Cao Y, Greten FR and Li ZW: NF-kappaB in cancer: From innocent bystander to major culprit. Nat Rev Cancer 2: 301-310, 2002.

18. Li Q and Verma IM: NF-kappaB regulation in the immune system. Nat Rev Immunol 2: 725-734, 2002.

19. Orlowski RZ and Baldwin AS Jr: NF-kappaB as a therapeutic target in cancer. Trends Mol Med 8: 385-389, 2002.

20. Deveraux QL and Reed JC: IAP family proteins-suppressors of apoptosis. Genes Dev 13: 239-252, 1999.

21. Liang Y, Zhou Y and Shen P: NF-kappaB and its regulation on the immune system. Cell Mol Immunol 5: 343-350, 2004.

22. Subbarmaiah K and Dannenberg AJ: Cyclooxygenase 2: A molecular target for cancer prevention and treatment. Trends Pharmacol Sci 24: 96-102, 2003.

23. Bogdan C: The multiplex function of nitric oxide in (auto) immunity. J Exp Med 187: 1361-1365, 1998.

24. Bogdan C: Nitric oxide and the immune response. Nat Immunol 2: 907-916, 2001

25. Moncada S: Nitric oxide: Discovery and impact on clinical medicine. J R Soc Med 92: 164-169, 1999.

26. Gong QH, Wu Q, Huang XN, Sun AS, Nie J and Shi JS: Protective effect of Ginkgo biloba leaf extract on learning and memory deficit induced by aluminum in model rats. Chin J Integr Med 12: 37-41, 2006.

27. Ilbey YO, Ozbek E, Simsek A, Otunctemur A, Cekmen M and Somay A: Potential chemoprotective effect of melatonin in cyclophosphamide- and cisplatin-induced testicular damage in rats. Fertil Steril 92: 1124-1132, 2009.

28. Zaninotto F, La Camera S, Polverari A and Delledonne M: Cross talk between reactive nitrogen and oxygen species during the hypersensitive disease resistance response. Plant Physiol 141: 379-383, 2006.

29. Kim SF, Huri DA and Snyder SH: Inducible nitric oxide synthase binds, S-nitrosylates and activates cyclooxygenase-2. Science 310: 1966-1970, 2005. 
30. Scobie IN, Saunders J, Barnes GD, Hoad J, Wheeler MJ, Lowry C, Sonksen PH, Amphlett G and Riley AJ: A comparative study of the effects of ranitidine and cimetidine on carbohydrate tolerance, growth hormone secretion and the hypothalamic-pituitary-gonadal axis in man. Curr Med Res Opin 10: 285-290, 1986

31. Kyriakis JM and Avruch J: Mammalian mitogen-activated protein kinase signal transduction pathways activated by stress and inflammation. Physiol Rev 81: 807-869, 2001.

32. Bubici C, Papa S, Dean K and Franzoso G: Mutual cross-talk between reactive oxygen species and nuclear factor-kappa $B$ : Molecular basis and biological significance. Oncogene 25: 6731-6748, 2006.

33. Bowie A and O'Neill LA: Oxidative stress and nuclear factor-kappaB activation: A reassessment of the evidence in the light of recent discoveries. Biochem Pharmacol 59: 13-23, 2000.

34. Hoesel B and Schmid JA: The complexity of NF- $\mathrm{BB}$ signaling in inflammation and cancer. Mol Cancer 12: 86, 2013.

35. Erl W, Hansson GK, de Martin R, Draude G, Weber KS and Weber C: Nuclear factor-kappa B regulates induction of apoptosis protein-1 expression in vascular smooth muscle cells. Circ Res 84: 668-677, 1999.

36. Rodriguez MS, Thompson J, Hay RT and Dargemont C: Nuclear retention of IkappaBalpha protects it from signal-induced degradation and inhibits nuclear factor kappaB transcriptional activation. J Biol Chem 274: 9108-9115, 1999.
37. Karin M: How NF-kappaB is activated: The role of the IkappaB kinase (IKK) complex. Oncogene 18: 6867-6874, 1999.

38. Ricciotti E and FitzGerald GA: Prostaglandins and inflammation. Arterioscler Thromb Vasc Biol 31: 986-1000, 2011.

39. Lue Y, Sinha Hikim AP, Wang C, Leung A and Swerdloff RS: Functional role of inducible nitric oxide synthase in the induction of male germ cell apoptosis, regulation of sperm number and determination of testes size: Evidence from null mutant mice. Endocrinology 144: 3092-3100, 2003.

40. Napli C, Paolisso G, Casamassimi A, Al-Omran M, Barbieri M, Sommese L, Infante T and Ignarro LJ: Effects of nitric oxide on cell proliferation: novel insights. J Am Coll Cardiol 62: 89-95, 2013.

41. Sharma JN, Al-Omran A and Parvathy SS: Role of nitric oxide in inflammatory diseases. Inflammopharmacology 15: 252-259, 2007.

This work is licensed under a Creative Commons Attribution-NonCommercial-NoDerivatives 4.0 International (CC BY-NC-ND 4.0) License. 